\title{
The Theory of Hegemony: Laclau's Path Not Taken
}

\section{Andro Kitus}

The State University New York, USA; University of London, UK

\begin{abstract}
The article revisits the theory of hegemony of Ernesto Laclau and Chantal Mouffe and shows how a normative injunction, which according to Laclau is not compatible with the hegemonic logic, is not only possible but a necessary condition for hegemony to function. The article claims that the path to demonstrate this involves rethinking the relationship between the theory of hegemony and Derridean deconstruction. Following criticisms that the theory of hegemony overlooks the aporetic nature of Derridean undecidability that it nevertheless relies upon, the hegemonic logic is submitted to a deconstructive reading, which reveals an internal aporia in it. It is further argued that the unaccounted aporia in the logic of hegemony explains the theory's inability to satisfactorily account for its essential theoretical underpinning, the radical exclusion. However, the article also demonstrates that the aporia does not destroy hegemonic logic but, instead, supplements it by a normative dimension, by a demand of opening to the other as other.
\end{abstract}

Keywords

antagonism, deconstruction, Derrida, empty signifier, ethics, hegemony, Laclau, normativity, post-Marxism

\section{Introduction}

The theory of hegemony developed by Ernesto Laclau and Chantal Mouffe occupies an ambivalent position in the field of political theory. On the one hand, their theory has stood the test of time, its description of the dynamics of the social/political sphere is considered revelatory and it has been used in countless analyses of political and cultural phenomena. On the other hand, there is a certain dissatisfaction with some aspects of their theory, which continue to be criticized. ${ }^{1}$ 
This article revisits two criticisms of the theory of hegemony and develops an alternative response to them that remains inside the framework of the theory of hegemony but departs from what Laclau has offered. The first criticism concerns the relationship between the theory of hegemony and deconstruction. In a later elaboration of the theory, Laclau defines the theory of hegemony as a theory of decision that supplements the situation of undecidability produced by deconstruction (Laclau 1996a, 62). ${ }^{2}$ The view that the Derridean undecidability needs to be bridged by a decision has been criticized by many (Norval 2004; Rubenstein 2009; Thomassen 2005a). These criticisms clear the ground for arguing in the opposite direction that the theory of hegemony needs to be supplemented by Derridean understanding of aporia or undecidability, if it is to fully realize its potential.

The second criticism concerns a normative deficit in hegemony, first highlighted by Simon Critchley, which amounts to a charge that, without a normative dimension, the theory of hegemony would be simply 'the description of a positively existing state of affairs' that has no critical leverage (Critchley 2004, 117). I maintain that complementing the theory of hegemony with a normative dimension depends on rethinking its relation to deconstruction. In this sense, I take heed of Critchley's call that 'the [normative] deficit can be made good on the basis of another understanding of the logic of deconstruction', although, the ethics of deconstruction and the relation between hegemony and deconstruction is reconstructed here quite differently from what Critchley $(2004,117)$ suggests.

In responding to these criticisms, I develop a deconstructive approach to hegemony, which, as I argue, is a path possible, but divergent from Laclau’s psychoanalytical framing of the theory. In doing this, I do not cast this project in terms of contentions between psychoanalytical and deconstructive approaches in general, ${ }^{3}$ rather, I simply note that the psychoanalytical development of the theory has induced the criticisms under question and, 
at the same time, has not yet produced satisfactory answers. This is what makes it worthwhile to consider an alternative approach.

After some preliminary explication of the main logic of the theory of hegemony and the overview of criticisms of Laclau's interpretation of deconstruction, I proceed with a close deconstructive reading of the hegemonic logic, which exposes an aporia in it. I then argue that the unaccounted aporia manifests itself on the level of theory construction in its inability to account or meet its own definition of the radical outside, on which its logic ultimately depends. Finally, I demonstrate how the aporia does not dissolve hegemony but adds to it a normative injunction. The opening of a normative dimension in the theory of hegemony relates to a wider discourse on the inclusivity of and responsibility in the democratic polity and provides a new awareness about the means of critiquing power relations that try to exclude certain groups and demands.

\section{The theory of hegemony and its relation to deconstruction}

Laclau's and Mouffe’s theory of hegemony springs up from a Saussurean question, how signification is possible when meaning can be determined only differentially, that is, when the meaning of an element is determined by its relations to other elements (see Saussure 2011). This premise seems to indicate that without a delimited system of differences, signification would be infinitely deferred. At the same time, any direct signification of limits is equally impossible, for it would assume other elements beyond the system, which were but other differences. Laclau and Mouffe argue that the only way to solve this paradox is to think the 'beyond' in terms of a radical (or antagonistic) exclusion, which presents limits as interruptions (or dislocations) in the signification process, rather than being directly signified. Nevertheless, a mere exclusion can never 'ground' a system, because all the elements in opposition to the excluded element(s) turn into equivalences, which cancels 
differential relations. Hence, as Laclau puts it, the exclusion 'which makes difference possible is also what makes it impossible’ (Laclau 2003).

The theory of hegemony applies this linguistic logic to the social field, where the system of elements starts to refer to (never fully constituted) society, and elements (or signifiers) become social demands for fulfilment of unsatisfied needs. Laclau and Mouffe argue that the differential and equivalential logics do not cancel each other out, but every demand becomes split between its particular content (differential dimension) and its universal part that results from common opposition against the excluded element(s) (equivalential dimension). Ultimately, the formation of the so-called equivalential chain of demands and the split in the demands is made possible by a demand (empty signifier) that mitigates (or empties of) its own particular content to the extent that it is able to become the surface of inscription for variety of other demands. This is called a hegemonic operation or the logic of hegemony. ${ }^{4}$ For example, echoing current political tendencies in many corners of the world, we can see how the term immigration occupies the role of the empty signifier. In that case, the question of limiting immigration starts to function as an inscription surface for many other demands that are not directly related to it. The satisfaction of various demands, such as demands for jobs, a higher work pay, lower crime rates, rights of cultural and religious expression, starts to depend on tackling of the issue of immigration; it is perceived that solving the issue of immigration leads to the solution of all these other problems. In terms of the theory of hegemony, the term 'immigration' is emptied from its specific content and is overdetermined by all these different demands with which it has no natural link. These demands become equivalent to each other as much as they are united by a common enemy, an immigrant that is perceived to upset the functioning of the otherwise harmonious society. 
In formulating this hegemonic logic, deconstruction was an important source of inspiration from the very beginning, being seen by Laclau and Mouffe to undo the sedimentation of power relations, which prepares the ground for hegemonic articulations (see Laclau and Mouffe 2001, xi). Later, in the book Deconstruction and Pragmatism, Laclau gives a succinct formulation of the relation between the theory of hegemony and deconstruction: ${ }^{5}$

Deconstruction and hegemony are the two essential dimensions of a single theoretico-practical operation. Hegemony requires deconstruction: without the radical structural undecidability that the deconstructive intervention brings about, many strata of social relations would appear as essentially linked by necessary logics and there would be nothing to hegemonize. But deconstruction also requires hegemony, that is, a theory of the decision taken in an undecidable terrain: without a theory of the decision, that distance between structural undecidability and actuality would remain untheorized. (Laclau 1996a, 62)

For Laclau, deconstruction exposes structural undecidability and contingency of the social field, where contingency refers to a 'condition from which no course of action necessarily follows' (Laclau 1996b, 78). This, in turn, highlights the need for a decision and for a theory to explain how the decision is possible in the situation of undecidability. Hence, 'the role of deconstruction is ... to reactivate the moment of decision', and hegemony as if completes deconstruction by providing for a theory of the decision in these circumstances (Laclau 1996b, 78). As a result, a clear dividing line between two theoretical moves can be drawn: the first move, deconstruction, is complemented by the second one, hegemony. Laclau has subscribed to this position also in his later interviews: 'deconstruction stops ... 
at the moment of undecidability. A theory of hegemony needs a further step - a theory of the decision - and that is not provided by deconstruction' (Laclau, Price, and Sutherland 2008).

The view that hegemony and deconstruction are complementary theoretical steps has provoked several criticisms. For example, Aletta Norval insists that deconstruction means something more and different than just a 'foregrounding of contingency' and that the Derridean undecidability should be kept apart from a mere structural openness:

Structural openness points to the essential contestability of all identity and the ultimate impossibility of closure. Undecidability, by contrast, designates a terrain, not of general openness and contestability, but of a regulated tension and of a suspension in the "between" (Norval 2004, 146-47).

Norval's main charge against Laclau is that he ignores a specific connotation of the Derridean undecidability as an infrastructure (Norval 2004, 141, 146). Norval's critique is echoed by Lasse Thomassen, who states that 'deconstruction and hegemony, undecidability and decision, can neither be temporally separated, nor conceived as different and complementary analytical moves' (Thomassen 2005a, 291). It is because, as Mary-Jane Rubenstein's critique explains it, 'the height of undecidability and the ground of decision inhabit the same spatiotemporal instant’ (Rubenstein 2009, 177). There is no undecidability without decidability. I will return to some aspects of these criticisms below.

These criticisms suggest a possibility that despite an elaboration of the theory of hegemony 'in a “deconstructive” style’, as Derrida puts it, deconstruction remains partially unaccounted in hegemony's workings (Derrida 2006, 226, fn 31). If this is the case, then the unaccounted deconstructive movement reveals itself in aporias it inevitably produces 
in the hegemonic logic. The following deconstructive reading of the logic of in/exclusion in hegemony uses the conceptual framework of the theory of hegemony against itself to reveal its conditions of possibility. The analysis will remain, therefore, inevitably tied to the rather abstract conceptual framework of Laclau's theory, but I hope that the inserted examples will offer a reader at least some material reference points.

\section{Re-examining the logic of in/exclusion in hegemony}

The whole dynamics of Laclau's theory hinges on how it conceives the inclusion of new elements into and their exclusion from the equivalential chain. For that reason, the logic of in/exclusion in hegemony is the best starting point for a deconstructive analysis. At first sight, it might seem that the theory of hegemony does not allow any conflict between a tendentially empty signifier (e.g. immigration, as in the example above) and other demands in the equivalential chain (e.g. better job opportunities, work pay, etc.). After all, the demands in the chain invest in an empty signifier in the hope that their needs will be met, which should make the conflict impossible. However, Laclau also claims that the equivalential chain is essentially unstable and 'no empty signifier can fully control which are the links which will be part of that chain' (Laclau 2006, 108). If the empty signifier were to control the chain perfectly, it would fix its parameters permanently and any hegemonic rearticulation would be impossible. It should be also kept in mind that the empty signifier does not unify the chain by way of conceptual subsumption, but by the act of naming, which does not set logical constraints for some deviations (see Laclau 2005, x, 118). However, if the empty signifier does not control the chain, conflicts between the empty signifier and some demands in the chain must be assumed possible in principle. This opens the question, what are the theoretical implications of this possibility. 
To clarify this, it is necessary to look at the dynamics between the equivalential chain and heterogeneity, which is an important concept in Laclau's later theory. According to Laclau, heterogeneity entails that 'a demand cannot be incorporated into the equivalential chain because it clashes with the particularistic aims of demands which are already links in that chain’ (Laclau 2005, 139). However, this rejection of heterogeneous elements by the particular contents of demands in the equivalential chain cannot be assumed to be uniform; while some contents might be in conflict, others might be favourable to heterogenous elements, and still others are neutral. Thus, any demand in the chain has two main characteristics: it shares a common opposition to the antagonistic other, and its particular content is more in agreement with other contents in the chain than in conflict.

In the normal situation, if a heterogeneous element makes an attempt to link itself to the chain, it is perceived as an isolated and singular disturbance from the point of view of the chain. However, other scenarios are also possible: after some minor dislocatory event that changes the previous constellation of demands, an external element is able to link itself to the chain on the ground that its particular content is now acceptable for the majority of the chain. But if the chain is not uniform in relation to the new demand, the situation might rise where the particular content of the tendentially empty signifier sides with the minority in its negative attitude towards the new demand. So, on the one hand, the new demand is accepted into the chain, because the majority of demands in the chain has no issue with it (in addition to having a common opposition against the antagonistic other), but on the other hand, the particular content of the demand still remains in conflict with the (residue of) particularity of the empty signifier. Obviously, this situation cannot be, because the empty signifier represents by definition the whole chain, and therefore, this contradiction between particularities is a source of crisis that needs to be solved somehow. 
For example, let us assume that after the end of the occupation of a country, a group of citizens of that country seeks recognition for the 'freedom fighters', who had been excluded from the field of representation as terrorists by the old regime, with an act of erecting a monument for those killed in the fighting. Nevertheless, even if the antagonistic other is changed in the new political situation, the political elite does not want to be associated with this potentially controversial movement and decrees the act as illegal. However, in the changed discursive situation, the demand has been already linked to other demands in the equivalential chain by the reason of its standing against the common enemy, and the attempt to criminalize the demand is contested by society (as illegitimate), which leads to a crisis.

There are two peaceful ways out of this predicament. ${ }^{6}$ The first possibility is that the empty signifier dilutes its particular content even further, so that it can accommodate the new demand. The second option is that the empty signifier marginalizes the demand in such a way that the forces in the equivalential chain renounce their agreement with the particular aims of the new demand and allow the empty signifier to reaffirm the limits of the representative field, excluding the new demand once more as an isolated and singular disturbance (or alternatively, as a demand that belongs to the chain of the antagonistic other).

However, there are two other possible scenarios that lead to a general crisis. Both of these scenarios highlight the fact that the mechanisms of inclusion and exclusion take place in a sort of out of joint time: Although the empty signifier that creates the unity of the chain by setting up its limits has power, so to say, to exclude a new demand from the chain, this always must occur after the fact that this new demand has already linked itself to the chain, because it cannot (actively) control the limits of the chain; it is the equivalential chain as a whole that allows new demands to link with itself. So, the third possibility how the 
contradiction between the residual particularity of the empty signifier and the particular content of a new demand plays out is that the empty signifier still tries to exclude it, even if the demand is linked to the chain and is more in agreement than in conflict with other demands in the chain. As much as the new demand is seen by the chain as one among 'us', the exclusion is perceived as an act of violence directed against 'all of us', rather than the use of power against 'them'. As a result, the empty signifier loses its power to represent the chain and a wider crisis evolves further, leading to the emergence of a new empty signifier.

The three above described scenarios all remain in the parameters of Laclau's theory, but there is also a fourth option that is not immediately apparent and which I call here 'corruption'. Laclau's usage of the term corruption in New Reflections refers to the idea of dislocation in thought of classical antiquity, that is, forms of government become corrupted over time and are replaced in a cyclical fashion (Laclau 1990, 72). But this is not how the term is used here. Here, the term refers to the corruption of particular contents of demands (their linkage to the antagonistic Other) with the proviso that they can be reformed by purifying or sacrificing corrupted parts. And Laclau at least hints at this possibility, even if he does not develop it at any lengths: 'while individual demands get reinforced through their equivalential inscription, the chain as a whole develops a logic of its own, which can lead to a sacrifice or betrayal of the aims of its individual links' (Laclau 2005, 139). This might vaguely remind us the practice of modern-day governments who, having stirred up a major scandal, sacrifice few of its members to signal, on the one hand, their recognition of misbehaviour, but on the other hand, they lay blame for the scandal upon some corrupt parts of government, which are going to be eliminated.

In its radical form, the case can be played out in two different ways, of which the second is in our special interest. I dub the first version a 'witch-hunt' case. A new demand 
is accepted to the chain but argued to be corrupt in its particular content. (Of course, in principle, this fate can befall on any demand in the chain, be it new or 'old-established'.) In a typical medieval witch-hunt case in Europe, the person accused of witchcraft is excluded from the community, that is, she/he is sentenced to be purified of its corrupted part that is considered a source of misfortune suffered by the whole community (e.g. sickness, a crop failure, etc.). His/her exclusion from the community takes an interesting twist, for even if a part of his/her being is considered corrupt and linked to the antagonistic Other, she/he still remains in the community because of the universal part, that is, his/her soul, which is not called into question; the soul of the person remains sacred, even if the body is corrupted by the evil.

The second radical version of the corruption case is when the empty signifier itself, in its attempt to restore the 'meaningful' borders of the field of representation and exclude the new conflictual demand from the chain of equivalence, is dubbed as corrupt (but reformable). This means the particular content (or the residue) of the empty signifier is considered to be linked to an equivalential chain of the antagonistic Other, and it needs to be purified from the corruption. Rather than triggering a general crisis and the process of replacing of the empty signifier, its position remains taken by the 'same' signifier as much as it continues to be invested by the demands in the chain. Therefore, even if its (residue of) particular content is excluded from the chain, its universal part must remain in the chain. In other words, the exclusion takes place along the 'division' between the particular and the universal dimensions of the empty signifier. Thus, after the exclusion is executed, so to say, or the antagonistic frontier is redrawn, the universal part of the empty signifier, which represented the whole chain, cannot just disappear into thin air; it has to 'return' to the equivalential chain. But, at the same time, whatever 'returns' into the equivalential chain cannot uphold its difference from other demands, because it lacks any particular content. 
Therefore, unable to uphold its difference, the returning signifier, or better, the 'blank' of a signifier, marks out every demand in the equivalential chain and the chain itself.

On the one hand, this 'returning blank' of a signifier, in the manner it is sifted out here, appears as an exception, as if a discardable exception, but on the other hand, the possibility of this singular exception must be assumed to be a universal occurrence, and always already at work in the structure of hegemony. To demonstrate the universality of the 'act' of sacrificing a particular content that is playing the role of the empty signifier, I refer to three mythological creation stories of three cultures/religions most apart from each other. Firstly, we can learn from an ancient Akkadian epic Atrahasis from around $17^{\text {th }}$ century BC that the birth of mankind entails the sacrifice of a god Aw-ilu, whose spirit remains to animate clay and blood mixture what the human being is. Foster's rephrasing of the pertinent lines from the epic (lines 190-237) is as follows:

Kill the one god ( $A w$-ilu) who had the "inspiration" (timu) for the rebellion, purify the executioners, but let a "spirit" (elemmu) remain from the slain god, this to be part of new-created man (awilu). The pulsation of this spirit will be a perpetual reminder of the dead god. (Foster 1996, 167-8)

In our terms, god $A w$-ilu as an empty signifier must be sacrificed in order for its spirit (or its universal part) could animate the human being.

We find the same pattern in Aztec mythology as described in the Codex Florentine of friar Bernardino de Sahagún: the present age, or fifths sun of our world is created by the self-sacrifice of god Nanahuatzin who threw himself into the fire, transforming in this way into the fifths sun, and self-sacrifice of other gods put the sun and time in motion (AguilarMoreno 2006, 140-1, 161). The sun that gives life (the 'blank') is born out of the sacrifice of gods, that is, by the sacrifice of the particular content(s) of the empty signifier(s). 
Thirdly, the founding story of Christianity also fits well into the schema. If we stay on the level of story, then Jesus is excluded from the community of believers because of what he claims to be, i.e. because of its particular content in terms of hegemony. However, after crucifixion, after exclusion of its particular content, Jesus, as the son of God, returns to the community as their redeemer. It becomes a sort of a 'signifier' in which the community recognizes itself.

The 'blank' of the signifier will be explicated further below, but it suffices to point out here that in terms of the theory of hegemony, it is something like a pure universality, which disrupts the hegemonic logic. As much as the 'blank' of a signifier, emptied of all particularity, 'returns' to the equivalential chain and maintains its position as the empty signifier, it opens the chain indiscriminately to any demand, which would also result in the collapse of the antagonistic exclusion, or as Laclau puts it: 'If we could have an absolutely empty signifier, “universality” would have found its true and final body, and hegemony, as a way of constructing political meanings, would be at an end' (Laclau 2000, 305). Therefore, the 'blank' of a signifier constitutes a rupture in the logic of hegemony, which is not brought upon it from the outside, but it follows from the theory's own stipulation that the empty signifier does not control the equivalential chain. Such rupture indicates an incompleteness of the theory of hegemony, which must manifest itself in a certain inability to account for some of its essential elements. This will be examined next.

\section{The radical exclusion in the theory of hegemony}

In the following, I show that the default of the theory of hegemony that relates to the 'blank' of a signifier is its inability to account for the radical exclusion, or constitutive outside, which is essential for its logic. There are two criteria that define the radical exclusion in Laclau: it has no 'common measure with the "inside"' (Laclau 1990, 18), and it is not 
'simply one more, neutral element but an excluded one, something that the totality expels from itself in order to constitute itself...' (Laclau 2005, 70). In other words, the radical exclusion refers to an unreachable 'outside' and an act of exclusion. According to Laclau, the theory of hegemony accounts for the radical exclusion in the following way:

But if what we are trying to signify is ... a radical exclusion which is the ground and condition of all differences, in that case, ... it is only if the differential nature of the signifying units is subverted, only if the signifiers empty themselves of their attachment to particular signifieds and assume the role of representing the pure being of the system - or, rather, the system as pure Being - that such a signification is possible. (Laclau 1996b, 39)

This means that, on the ontological level of analysis, the radical exclusion makes differences equivalent, but by doing this, it also cancels the need for itself. It is the empty signifier that incurs the equivalential dimension, arresting in this way the endless cycle of offsetting. But there is a certain double bind in the role of the empty signifier in Laclau's theory. On the one hand, the empty signifier cannot be entirely empty, because it can only be a particularity that takes the role of the empty signifier. On the other hand, it must be empty, if the theory of hegemony wants to signify the radical exclusion, which manifests itself as an interruption of the signification process. One way to frame my critique is to argue that in responding to this double bind, he does not think aporetically but reduces one demand of the double bind to the other. When Laclau states that 'an empty signifier can, consequently, only emerge if there is a structural impossibility in signification as such, and only if this impossibility can signify itself as an interruption (subversion, distortion, etcetera) of the structure of the sign' (Laclau 1996b, 37), he actually equates (in 
parentheses) the two imperatives into one act of subversion. But I will show that the difference between these two demands must be uphold, for it differentiates subversion, or a political reform of the past, from an interruption, or a welcoming of the unknown future.

Laclau's response to this double bind is the construction of the horizon of universality as an ultimate signification of the equivalential dimension: 'The universal emerges out of the particular ... as an incomplete horizon suturing a dislocated particular identity’ (Laclau 1996b, 28). In emptying of its content, the empty signifier offers itself for an inscription surface of what is lacking in various other demands. By doing this, it promises fullness, which starts to function as a horizon (of an absent fullness). But nevertheless, if the horizon is theoretically constructed in such a way that it depends on the tendentially empty signifier, it always remains subordinated to it. This means that such imaginary horizon is not only named by but also understood in terms of a particular content of the empty signifier, as in Laclau's examples of 'the Christian millennium, the Enlightenment and positivism's conception of progress, communist society' (Laclau 1990, 64). In that case, the horizon is not 'autonomous' enough to signify the radical exclusion. At the same time, Laclau does not question the need for such horizon of universality for his theoretical construction, when he demands that 'the very form of objectivity must free itself from any concrete entity and assume the character of a horizon' (Laclau 1990, 64).

There seems to be also another theoretical construction of the horizon of universality in Laclau's work that might suggest a slightly different approach. In some texts, Laclau talks about 'autonomization' of the universal dimension that results from competition of particularities in assuming the role of the empty signifier (Laclau 1996b, 71). The process of 'a prior' emptying of all demands means that they all partake in the same emptiness, which then appears (via naming) as an autonomous horizon of universality, or the pure form of fullness, filled in by an empty signifier in the same movement, but still as if 'later'. 
It seems to point to a possibility that the tendentially empty signifier is 'divested' from its ontological significance by introducing a temporal delay into its emergence. However, this is conceivable only when a relative stabilization of differences already takes place on the basis of the radical exclusion, like, for example, Oliver Marchart argues: ‘The system’s constitutive outside - its exclusionary limit - stabilizes the system to some degree, thereby producing the very effect of systematicity (equivalence)' (Marchart 2004, 60). The problem is that this relative stabilization makes the delay possible, but at the same time, it also undermines its status, because it casts the tendentially empty signifiers or the "“relatively" universalized content', as Marchart puts it, at the ontic level (Marchart 2004, 66). This would mean that the hegemonic logic does not even seek to account for the radical exclusion and is happy to renounce its pretention to theorize the institution of a social order.

Although Laclau rejects the possibility of divesting empty signifiers from their ontological role (Laclau 2004, 311), Marchart follows this line of argument to its conclusion and tries to 're-introduce' the radical exclusion in his version of hegemony. He re-describes the radical exclusion in terms of ontological difference between Being and beings from Martin Heidegger's phenomenology, whereas tendentially empty signifiers belong to the ontic level and impossible extreme cases of these tendentially empty signifiers, that is, pure singularities and empty absolutes, as Marchart dubs them, belong to the ontological level. The radical exclusion, then, 'runs, in the "strict" or "radical" sense, between those more or less universalized contents on the one hand and the dimension of universality/particularity as such on the other' (Marchart 2004, 66, see also, 2007, 146-9). The analogy with the ontological difference should give us a sense how the impossible extreme cases are not excluded from the hegemonic logic, even if they are impossible in the sense that they annul the need for the hegemonic politics. Marchart concludes on this point: 
From the vantage point of hegemony theory, the singular and the absolute are an intrinsic "aspect" of the play between particular and universal. In some sense, they can even be said to be identical with the latter. And yet they are different in as much as they are necessarily impossible: the singular and the absolute are names for that state of particularity/universality which must remain necessarily impossible in order to function as condition for the possibility of the play between the particular and the universal. (Marchart 2004, 67)

There is no objection to this description per se, but according to the logic of construction of this theory, the redescription of the radical exclusion as the ontological difference can be understood only to account for a partial or a relative stabilization of the signifying system. The partiality of stabilization cannot refer here to the instability that emanates from the radical exclusion itself, because the radical exclusion does not explain or signify its own possibility. Therefore, there are only two options: whether the radical exclusion in this theory is still less than the ontological difference, or there must be a 'beyond' of ontological difference, a still more radical difference that explains the radical exclusion and the ontological difference itself. However, there is no means to account for this 'beyond' in the theory of hegemony (see also Derrida 1982).

For the same reasons, Laclau struggles to find something equivalent to the radical exclusion on the discursive field. Even if Laclau identifies in the quoted passages above the criteria of unreachability and the act of exclusion as defining the radical exclusion, he seems to understand one through the other, so that the consciously expelled implicates its incommensurability. This also might explain why Laclau, in his initial formulation, collapses the radical exclusion into the notion of antagonism. On the one hand, he describes 
antagonism as 'the limit of all objectivity' (Laclau 1990, 17), in which case the notion of antagonism refers to the constitutive outside. On the other hand, Laclau describes it as a situation where 'the presence of the "Other" prevents me from being totally myself' (Laclau and Mouffe 2001, 125), which is only one possible discursive manifestation of the radical exclusion (Thomassen 2005b, 107). Later, Laclau revised his initial position, admitting that the radical exclusion needs not to be antagonistic and that the antagonistic construction of the constitutive outside is not the radical exclusion, because 'what it does is to dichotomize the social space, but both sides of the antagonistic relation are necessary in order to create a single space of representation' (Laclau 2004, 319). From that point on, Laclau sees antagonism as ‘a form of discursive inscription’ of dislocation, which seeks to pacify this internal instability. However, the notion of dislocation cannot replace antagonism, because the dislocation is part of the system as an experience and an effect of the radical exclusion, that is, the manifestation of the instability of the system.

After redefining antagonism, Laclau develops a different type of 'exclusion’ heterogeneity, which refers to elements that 'cannot be assimilated to the inclusive exclusion of antagonism', that is, it refers to elements that have no access to the field of representation (Laclau 2004, 319). Even if in this case that the exclusion 'presupposes exteriority not just to something within a space of representation, but to the space of representation as such' (Laclau 2005, 140), what is missing in this kind of 'exclusion' is exclusion. Heterogeneous elements 'appear' on the representative field as (criminal) disturbances, and as such, they are not excluded but penalized and dissolved. In short, the conclusion of Paula Biglieri and Gloria Perelló seems to be pertinent: 'these three elements should not be considered as one surpassing the other, i.e. as dislocation surpassing antagonism and heterogeneity surpassing dislocation', but each is focusing on a specific aspect of hegemonic logic (Biglieri and Perelló 2011, 61). This however does not solve the 
theoretical problem: one way or another, the theory of hegemony is not able to meet its own definition of the radical exclusion. The next task is to show that the 'blank' of a signifier needs not to destroy the logic of hegemony, even if it resembles the pure universal in term of the theory of hegemony, but it remains into its logic as a persistent possibility.

\section{Possibility of the 'blank’ of a signifier}

There are two theoretical conditions that need to be met for the 'blank' of a signifier to be possible in the logic of hegemony. Firstly, to 'return', the 'blank' of a signifier has to hold together with itself (as it has no content), and secondly, this holding together should not amount to being a signifier; it does not return to replace an empty signifier or to become a 'transcendental place', which would be filled in by it. Laclau seems to view any such figure or movement inevitably as a transcendental or external relation, which he considers impossible a priori: 'If identities are exclusively relational, then all relation must, by definition, be internal. The concept of an "external relation" has always seemed inconsistent to me’ (Laclau 1990, 207; see also, Berns 1996, 77). Therefore, in the coordinates of Laclau's theory, there is no possibility of such a 'transcendental constitution' of the chain, rather, the empty signifier functions as an act of naming that 'performatively brings about the unity of those elements' (Laclau 2005, 183). Clearly, however, what is here proposed as the 'blank' of a signifier is not thought as the transcendental place waiting there to be filled in with a content, but something that functions as the 'blank' in the Derridean sense, that is, what marks everything blank 'plus the blankness that allows for the mark in the first place'. In other words, the 'blank' of a signifier marks here an aporetic movement in the hegemonic logic; it functions as a socalled Derridean infrastructure. ${ }^{7}$ 
To show the possibility of the 'blank' of a signifier, let us take a closer look at what the so-called purification of the corrupt particularity of the empty signifier exactly entails. Above all, it symbolizes the excising of everything that did not let the equivalential chain to be 'what it is'. Therefore, what 'returns' in the figure of the 'blank' of a signifier is a knowledge or recognition of what the equivalential chain 'is', or what it aspires to be. Obviously, a direct knowledge about it would be totalizing and unifying of the chain prior to and instead of the empty signifier, but as there is no particularity attached to the 'returning blank' of a signifier, it must be assumed that even if there is something to be known, no member of the equivalential chain can tell with any certainty what it is. In other words, the purification of the empty signifier from corruption is supposed to make the chain knowledgeable about its 'better nature', but no member of the chain can have access to that knowledge. The way to think that there still is a knowledge in this situation, which is important for it to have effects, is through the concept 'others supposed to know', which borrows from the concept 'the subject supposed to know' of Jacques Lacan's psychoanalytical theory. ${ }^{8}$ In the context of this discussion, it means that such knowledge appears for any member of the chain on the supposition that there are others who know. Matthew Sharpe has employed an example of national identity to explain the concept;

Though we ourselves can never simply state what [our national identity consists in] ..., what is nevertheless efficient in generating our belief in (and identification with) this elusive "thing" is a conviction that nevertheless other people certainly know its nature, or seem to. (Sharpe n.d.) 
To put it in Lacanian terms, the signifier is not compensated for the lack of the signified by an imaginary signified, but everything depends on the transferential supposition 'others supposed to know'.

Thus, it is proposed here that on the basis of this transferential supposition 'others supposed to know', the 'blank' of a signifier holds itself together without a determinate particular content, and also, it holds together, in itself, the whole chain, that is, it marks out every demand in the chain, but also their being a chain. But as it will be shown below, this 'being a chain’ does not close the chain; it can be thought closed only when kept (infinitely) open. Having established the possibility of the 'blank’ of a signifier in the hegemonic logic, I next outline its consequences for the theory of hegemony by responding to criticisms levelled against three of its aspects, that is, normativity, decision and the subject.

\section{Re-evaluation of criticisms: Normativity, decision, the subject}

The theory of hegemony is widely criticized for lacking a normative dimension in its logic. For example, Simon Critchley argues that ‘Laclau’s theory of hegemony requires an ethical dimension of infinite responsibility to the other if it is not going to risk collapsing into the arbitrariness of a thoroughgoing decisionism' (Critchley 2004, 116; see also, Devenney 2004; Šumič 2004). However, Laclau has always repudiated these proposals by arguing that 'I do not see in what sense an ethical injunction, even if it only consists of opening oneself to the otherness of the other, can be anything else than a universal principle that precedes and governs any decision' (Laclau 1996a, 55). To show how the 'blank' of a signifier allows and demands such injunction in the theory of hegemony, I return to Laclau's interpretation of undecidability, which has been criticized for overlooking its second more specific connotation as a Derridean aporia. 
Above, I showed that the 'blank' of a signifier disrupts the hegemonic logic, because the universal part of the expelled corrupt empty signifier 'returns' to the equivalential chain and opens it to any other demand. In terms of deconstruction, it is the situation of aporia, because in attempting to bridge the aporia of undecidability, the hegemonic logic produces its own impossibility by re-enacting the undecidability in itself. Derrida describes aporia as 'the impossible passage', 'the nonpassage', which can be 'the event of a coming or of a future advent' (Derrida 1993, 8). It is the arrival to a situation 'where it would no longer be possible to constitute a problem, a project, or a projection;' as when approaching a nonpassage, towards an aporia, the closer one gets to it, the fewer expectations he/she can have about what will come or happen to him/her, until there are none left (Derrida 1993, 12). As much as this leaves no object or border behind which to hide, this is also the moment of absolute exposure or openness to the unknown, the non-appropriable, the absolute arrivant, as Derrida puts it, who or what 'does not yet have a name or an identity' (Derrida 1993, 34). In this moment of aporia, I am 'delivered to the other', who decides 'on me in me', for which I shall take full responsibility (Derrida 1993, 12; 1997, 67).

However, and this is important to notice, this moment of aporia, of nonpassage cannot be fully experienced, because 'the experience finds its way, its passage, it is possible. And in this sense, it is impossible to have a full experience of aporia, that is, of something that does not allow passage' (Derrida 1990, 947). This means that aporia is encountered, or 'faced,' so to speak, in decision, in the 'space' of decision, where experience precisely is discontinued. This would be a paradoxical decision, because 'certainly the decision makes the event, but it also neutralizes this happening...' (Derrida 1997, 68). In other words, such decision must also remain in the 'space' of aporia and not undo the aporia, that is, it cannot take place before or after the aporia. If the decision took place prior to the aporia, the aporia or the openness to the other, that it entails, would appear as a project for the decision, which 
contradicts what aporia is; if the decision came after, it would decide or bridge the aporia. It follows that on the one hand, aporia forms in decision, but on the other hand, in a certain indecision, because the decision in aporia must remain unfinished, as if in the state of infinitely deciding. Therefore, such decision could not replace the decision of the other who is still to come and for which the 'I' takes full responsibility. Eventually, what emerges is a certain undecidability or the 'perhaps' in regard to the decision, as Derrida puts it: 'The aporia of the event intersects with ... the aporia of decision with regard to the perhaps' (Derrida 1997, 68). No one can tell is there perhaps decision or rather indecision in aporia.

Situating aporia in decision is the crucial element in showing how the ethics of responsibility emerges in deconstruction. ${ }^{9}$ Any decision, as much as it does not follow a calculation or programme, entails full responsibility for what is made possible by it. In its first movement, there is responsibility for all and anyone or anything who or what might come, and the aporia does not take anything away from this responsibility but rather accentuates it. In the moment of aporia where one is absolutely defenceless, without a project or identity, one would not be in the position to refuse responsibility that comes with the decision, making him or her more responsible than ever for what aporia makes possible. Still, this responsibility for and openness to all cannot turn into a prescription that guides decision, because there is an immediate second movement, in which the decision remains unfinished and infinite, and the responsibility for anyone and anything gives space to a responsibility for the decision of the other about this or that. This, however, does not mean that the possibility of a normative injunction is erased, because it is in a certain sense (re)created by the very undecidedness or the 'perhaps' in regard to the decision in aporia, that emerges as a result of its unfinished and infinite character. In the analysis of Blanchot's 'Three Voices of Marx', Derrida restates Blanchot's thought that the demand 'can never be always present, it can be, only, if there is any, it can be only possible, it must even 
remain a can-be or maybe in order to remain a demand' (Derrida 2006, 39). This means that if the decision of the other on this or that appears in the 'space' of aporia and for which one takes full responsibility, the responsibility for all, for anyone or anything who or what might come remains haunting and insisting in that decision as a normative demand that emanates from the undecidedness, the 'perhaps' of the decision in aporia. It is not perhaps a definite prescription, but there still is an ethical demand that continues coming back as a ghost, because the responsibility for all cannot be claimed done or finished finally.

In sum, aporia then is not a fork of the road, in front of which one stops to decide which way to go; the aporia is not when one can take time to make a decision to bridge the undecidability. Whenever this is the case, one has not thought aporia aporetically, which might be the root of Laclau's misreading. Aporia as the 'nonpassage' brought into the logic of hegemony by the 'blank' of a signifier, embodies an unfinished decision that makes the responsibility for all to inhabit hegemony as a possibility. This means that it is always possible for hegemony to be open to any other, and this possibility, as it is necessary, is always demanding consideration - there is a certain injunction. Even if the injunction does not amount to a knowledge or an unconditional prescription, this does not mean that there is a complete ignorance about how to decide. At the same time, this undecidability between knowledge and ignorance is constitutive of its insistence. It institutes a debt to the other: even if not all guests, strangers or immigrants can be accepted, there is always a prior indebtedness to accept them unconditionally. There can be no refusal by right. By inscribing the 'blank' of a signifier into the equivalential chain, this openness to the other as other remains to haunt any hegemony. ${ }^{10}$

The developed aporetic understanding of aporia also helps to respond to criticism regarding subjectivity and highlight the aspect of repetition (or a constative dimension) in hegemony. Laclau, on the one hand, clearly distances himself from any metaphysics of 
subjectivity and argues that the subject does not precede the decision. On the other hand, the only means to depict the moment of the decision in the theory of hegemony is to say that it is an instance of 'impersonating a God'; 'we “mortal Gods” ... simulating being Him and replacing with the madness of our decisions an omniscience that will always elude us' (Laclau 1996a, 57, 59). Rubenstein aptly remarks that "“acting as if” one were a subject is tantamount to “being” a subject, insofar as the myth of subjectivity has always been a myth’ (Rubenstein 2009, 149; see also, Miller 2004, 224-5). What the 'blank' of the signifier as an aporia adds to hegemony is the idea that the decision is always received from the other, or as Derrida says: 'My decision can never be mine; it's always the other's decision in me, and in a way, I am passive in the decision-making' (Derrida 2007, 455). Such passive decision then avoids positing the subject, inadvertently or not, before the decision and it cannot be by any means described as an impersonification of God.

The passive decision also supplements the performative nature of Laclau's theory with a constative dimension. ${ }^{11}$ What the 'blank' of a signifier highlights is that the empty signifier in Laclau's theory includes a citation not because it refers to its particular content (because it itself is one), ${ }^{12}$ but rather because the empty signifier, as much as each demand in the equivalential chain is already marked by the returning 'blank' of a signifier, always also repeats what the chain already 'is'. This original repetition inscribes a constative moment into hegemony's performative act of naming, but it does not mean that the constative replaces the performative. Rather, it introduces a certain originary undecidability into the hegemonic logic: from the very start, it is not clear whether the hegemonic signifier produces performatively the unity of the equivalential chain or it merely constates what the chain already is (see also Derrida 2002). This undecidability creates for the demands in the equivalential chain some distance and freedom from the hegemonic signifier understood as a fixative principle of all meaning, because it is never entirely clear whether the empty 
signifier offered anything beyond what they already were. In this way, the 'blank' of a signifier also responds to the critics who have called for rethinking the role of the political subject in the theory of hegemony. For example, Christian Lundberg sees the necessity for the theory of hegemony to develop 'a political subject in the sense of being able to truly argue for something without being dependent on the other as a support for or organizing principle for political identity' (Lundberg 2012, 12). By inscribing the 'blank' of a signifier into the hegemonic logic, any particular empty signifier or any political force occupying this position is always already put into question, and made accountable beyond its own program, for it always also is to repeat what the equivalential chain already is.

\section{Conclusion}

This article showed that the deconstructive reading of the theory of hegemony reveals an aporia, the 'blank' of a signifier, inside the hegemonic logic. Instead of offering a theory of decision on an undecidable terrain, the theory of hegemony remains itself permeated by a more 'older' and radical undecidability than what follows from the unachievability of the fullness of society that continues 'haunting the structure as the presence of its absence' (Laclau 1996a, 58). Rather, what is properly haunting in hegemony is the presence of an absence as absence, which differentiates any subversion of signification in (and from) itself, making the interruption of signification appear not just as its subversion but as a sort of re-subversion. The condition to think such possibility of impossibility in hegemony is an aporetic understanding of aporia, which does not seek to bridge the latter but endures it as an acceptance of the other. As a consequence, the theory of hegemony is supplemented by a normative dimension, because the aporia, the 'blank' of a signifier, opens the equivalential chain to any other infinitely, and this possibility continues to demand consideration in every decision. This also means that hegemonic theorizing itself cannot 


\section{be just a descriptive enterprise anymore, but it necessarily intervenes into the scene it narrates, because it itself desediments power relations and restates a hegemony’s openness to any other.}

\section{Notes}

This project has received funding from the European Union's Horizon 2020 research and innovation programme under the Marie Sklodowska-Curie grant agreement no 704479.

${ }^{1}$ For the best collection of criticisms, see Critchley and Marchart (2004).

${ }^{2}$ All references to the theory of hegemony beyond its initial form, which was developed by Chantal Mouffe and Ernesto Laclau in collaboration, are attributed to Laclau, whose writings elaborate the theory into its present shape.

3 The relationship between deconstruction and psychoanalysis has been contentious subject matter in the academic literature from the start of these movements. For arguments claiming that Derrida misreads Lacan, one can see, for example, Hurst (2008), or Lewis (2008). For a case supporting Derrida's deconstruction of psychoanalysis see, for example, Cornell (1997). On Laclau’s usage of Lacan, see Norval (2005).

${ }^{4}$ All Ernesto Laclau's writings in one way or another repeat this general logic of hegemony and explicate it from different angles; for an example, see ‘Why do Empty Signifiers Matter to Politics?’ in Emancipations (Laclau 1996b). 5 On the one hand, Laclau has always considered his project of hegemony itself deconstructive or, at least, indebted to deconstruction; in New Reflections of Our Time, he notes that 'in Hegemony and Socialist Strategy the project of a radical democracy was presented through a deconstruction of the history of Marxism as its starting point' (Laclau 1990, 4). At that time, as it is stated in an interview from 1988, he defines deconstruction through the notion of 'constitutive outside': 'Deconstructing an identity means showing the "constitutive outside" that inhabits it...' (Laclau 1990, 192). On the other hand, Laclau has refused to equate the notion of hegemony with spectrality from Derrida's deconstruction of Marxism in Specters of Marx: 'I hesitate, however, to entirely endorse such an apparently obvious assimilation. Although there is no incompatibility between hegemony and spectral logic as far as the latter goes, a hegemonic logic presupposes two further steps beyond spectrality...' (Laclau $1996 \mathrm{~b}, 70)$. 
${ }^{6}$ A taxonomy of possible responses to dislocations in the hegemonic politics is also outlined by Torben Bech Dyrberg in The Circular Structure of Power: Politics, Identity, Community (Dyrberg 1997, 143-4).

${ }^{7}$ There is no space here to give a full account of Derrida's analysis in 'The Double Session' of the figure of the blank and the fold in Stéphane Étienne Mallarmé's work, or even fully to compare it with what is being ventured in this article, but for the purposes of illustration, I extract in the most economical (and violent) way a quote from his text to give a sense of the 'blank' as a Derridean infrastructure. So, for Derrida 'the "blank" inserts ... the blank as a blank between the valences, a hymen that unites and differentiates them in the series, the spacing of "the blanks" ... This non-sense or non-theme of the spacing ... cannot be accounted for by any description. ... And since it has no meaning, it is not The blank proper, the transcendental origin of the series. ... Through an interruption that suspends the equation between the mark and the meaning, the "blank" marks everything white (this above all) ...plus the blankness that allows for the mark in the first place, guaranteeing its space of reception and production. This "last" blank (one could equally well say this "first" blank) comes neither before nor after the series. ... The supplementary "blank" ... prevents any semantic seriality from being constituted, from being simply opened or closed ... [nevertheless, it] actually liberates the effect that a series exists; in marking itself out, it makes us take agglomerates for substances' (Derrida 2004, 252-4).

${ }^{8}$ Jacques Lacan develops the concept 'the subject supposed to know' for the psychoanalytical theory in his The Four Fundamental Concepts of Psychoanalysis (Lacan 1998, 240-43). A variation of this concept 'the other supposed to know/believe' has been used in the context of social/political analysis by Slavoj Žižek; for example, see The Plague of Fantasies ('̌ižek 2009, 136-8).

${ }^{9}$ The literature on the ethics of deconstruction is extensive, see, for example, Anderson (2012), Gaon (2019) and Raffoul (2010).

${ }^{10}$ Jelica Šumič calls for a similar ethical injunction and relates it to the question of the possibility of emancipation in the hegemonic framework; she proposes to delineate in the traditional role of empty signifier a separate role of 'detotalizing', which 'makes it possible for a community 'for all' to come into being' (Šumič 2004, 194-5). In its intention, this theoretical move does not stand far from what is proposed here under the 'blank' of a signifier.

11 The performative-constative distinction originally comes from Austin's speech act theory, where performatives refer to speech acts that do things and constatives describe states of affairs (Austin 1962). Derrida's analysis of Austin's work adds the provision that performatives always imply constatives; that is, there are no pure performatives (Derrida 1988). 
12 This is the position maintained by Lasse Thomassen (see Thomassen 2005b, 106).

\section{References}

Aguilar-Moreno, Manuel. 2006. Handbook to Life in the Aztec World. New York: Infobase.

Anderson, Nicole. 2012. Derrida: Ethics Under Erasure. London and New York: Bloomsbury.

Austin, J. L. 1962. How to Do Things with Words. The William James Lectures Delivered at Harvard University in 1955. Edited by James O. Urmson. London: Clarendon Press.

Berns, Egid E. 1996. "Decision, Hegemony and Law: Derrida and Laclau." Philosophy \& Social Criticism 22, no. 4: 71-80.

Biglieri, Paula, and Gloria Perelló. 2011. "The Names of the Real in Laclau's Theory: Antagonism, Dislocation, and Heterogeneity.” Filozofski Vestnik 32 no. 2: 47-64.

Cornell, Drucilla. 1997. "Where Love Begins: Sexual Difference and the Limit of the Masculine Symbolic." In Derrida and Feminism: Recasting the Question of Woman, edited by Ellen K. Feder, Mary C. Rawlinson and Emily Zakin, 161-206. New York: Routledge.

Critchley, Simon. 2004. "Is There a Normative Deficit In the Theory of Hegemony?" In Laclau: A Critical Reader, edited by Simon Critchley and Oliver Marchart, 113-22. New York: Routledge.

Critchley, Simon, and Oliver Marchart. 2004. Laclau: A Critical Reader. Edited by Simon Critchley and Oliver Marchart. New York: Routledge.

Derrida, Jacques. 1982. “Différance.” In Margins of Philosophy, 1-27. Brighton, UK: The Harvester Press.

\section{Press.}

1988. Limited Inc. Edited by Gerald Graff. Evanston, IL: Northwestern University

1990. "Force of Law: The 'Mystical Foundation of Authority." Cardozo Law Review 11: 921-1045.

. 1993. Aporias: Dying - Awaiting (One Another At) the "Limits of Truth". Stanford, CA: Stanford University Press.

1997. Politics of Friendship. Phronesis. New York: Verso.

. 2002. "Declarations of Independence." In Negotiations: Interventions and Interviews, 1971-2001, edited by Elizabeth Rottenberg, 46-54. Stanford, CA: Stanford University Press. 
. 2004. “The Double Session.” In Dissemination. London and New York: Continuum.

2006. Specters of Marx: The State of the Debt, the Work of Mourning and the New International. New York: Routledge.

- 2007. "A Certain Impossible Possibility of Saying the Event." Critical Inquiry 33, no. 2: 441-61.

Devenney, Mark. 2004. "Ethics and Politics In Discourse Theory." In Laclau: A Critical Reader, edited by Simon Critchley and Oliver Marchart, 123-39. New York: Routledge.

Dyrberg, Torben. 1997. The Circular Structure of Power: Politics, Identity, Community. New York: Verso.

Foster, Benjamin R. 1996. Before the Muses: An Anthology of Akkadian Literature. Vol. I: Archaic, Classical, Mature. Bethesda: CDL Press.

Gaon, Stella. 2019. The Lucid Vigil: Deconstruction, Desire and the Politics of Critique. New York and London: Routledge.

Hurst, Andrea Margaret. 2008. Derrida vis-à-vis Lacan: Interweaving Deconstruction and Psychoanalysis. New York: Fordham University Press.

Lacan, Jacques. 1998. The Four Fundamental Concepts of Psychoanalysis: The Seminar of Jacques Lacan, Book XI. New York: W. W. Norton.

Laclau, Ernesto. 1990. New Reflections on the Revolution of Our Time. Edited by Ernesto Laclau. Phronesis. New York: Verso.

1996a. "Deconstruction, Pragmatism, Hegemony." In Deconstruction and Pragmatism, edited by Chantal Mouffe, 49-70. New York: Routledge.

—.1996b. Emancipation(s). Phronesis. New York: Verso.

—. 2000. "Constructing Universality." In Contingency, Hegemony, Universality: Contemporary Dialogues on the Left, edited by Judith Butler, Ernesto Laclau and Slavoj Žižek, 281-307. Phronesis. New York: Verso.

- 2003. "Philosophical Roots of Discourse Theory." Centre for Theoretical Studies in the Humanities and Social Sciences, University of Essex. Accessed June 25, 2007. http:/ /www. essex. ac. uk/centres/TheoStud/onlinepapers. asp.

. 2004. "Glimpsing the Future." In Laclau: A Critical Reader, edited by Simon Critchley and Oliver Marchart, 279-328. New York: Routledge.

- 2005. On Populist Reason. London; New York: Verso.

—. 2006. "Ideology and Post-Marxism.” Journal of Political Ideologies 11, no. 2: 103-14. 
Laclau, Ernesto, and Chantal Mouffe. 2001. Hegemony and Socialist Strategy: Towards a Radical Democratic Politics. London: Verso.

Laclau, Ernesto, Brian Price, and Megan Sutherland. 2008. "Not a Ground but a Horizon: An Interview with Ernesto Laclau.” World Picture. 2008.

http://www.worldpicturejournal.com/WP_2/Laclau.html.

Lewis, Michael. 2008. Derrida and Lacan: Another Writing. Edinburgh: Edinburgh University Press.

Lundberg, Christian. 2012. "On Being Bound to Equivalential Chains." Cultural Studies 26, no. 2-3: 299-318.

Marchart, Oliver. 2004. "Politics and the Ontological Difference: On the 'Strictly Philosophical' in Laclau's Work." In Laclau: A Critical Reader, edited by Simon Critchley and Oliver Marchart, 54-72. New York: Routledge.

- 2007. Post-Foundational Political Thought: Political Difference in Nancy, Lefort, Badiou and Laclau. Edinburgh: Edinburgh University Press.

Miller, Hillis J. 2004. “'Taking Up a Task’: Moments of Decision in Ernesto Laclau's Thought." In Laclau: A Critical Reader, edited by Critchley, Simon and Marchart, Oliver, 217-25. New York: Routledge.

Norval, Aletta. 2004. "Hegemony after Deconstruction: The Consequences of Undecidability." Journal of Political Ideologies 9, no. 2: 139-57.

- 2005. "Theorising Hegemony: Between Deconstruction and Psychoanalysis." In Radical Democracy: Politics Between Abundance and Lack, edited by Lars Tønder and Lasse Thomassen, 86-102. Manchester and New York: Manchester University Press.

Raffoul, François. 2010. The Origins of Responsibility. Bloomington and Indianapolis: Indiana University Press.

Rubenstein, Mary-Jane. 2009. Strange Wonder: The Closure of Metaphysics and the Opening of Awe. Insurrections. New York: Columbia University Press.

Saussure, de Ferdinand. 2011. Course in General Linguistics. New York and Chichester, UK: Columbia University Press.

Sharpe, Matthew. n.d. "Jacques Lacan." The Internet Encyclopedia of Philosophy. Accessed 12, 2018. https://www.iep.utm.edu.

Šumič, Jelica. 2004. “Anachronism of Emancipation or Fidelity to Politics.” In Laclau: A Critical Reader, edited by Simon Critchley and Oliver Marchart, 182-98. New York: Routledge.

Thomassen, Lasse. 2005a. "Antagonism, Hegemony and Ideology after Heterogeneity." Journal of Political Ideologies 10, no. 3: 289-309. 
. 2005b. "In/Exclusions: Towards a Radical Democratic Approach to Exclusion." In Radical Democracy: Politics Between Abundance and Lack, edited by Lars Tønder and Lasse Thomassen. Reappraising the Political, 103-119. Manchester and New York: Manchester University Press.

Žižek, Slavoj. 2009. The Plague of Fantasies. New York: Verso. 